\title{
Centrosome-Associated Protein 350
}

National Cancer Institute

\section{Source}

National Cancer Institute. Centrosome-Associated Protein 350. NCI Thesaurus. Code C131274.

Centrosome-associated protein 350 (3117 aa, $351 \mathrm{kDa}$ ) is encoded by the human CEP350 gene. This protein is involved in centriole growth. 